\title{
PENGARUH BRAND LOYALTY, BRAND LOVE, BRAND COMMITMENT TERHADAP WILLINGNESS TO PAY A PREMIUM PRICE
}

\author{
Trisno Pangestu \\ Program Studi Magister Manajemen Universitas Tarumanagara \\ trisnoacm@yahoo.com \\ Chairy \\ Program Studi Magister Manajemen Universitas Tarumanagara
}

\begin{abstract}
The purpose of this research is to evaluate the influence of family and non-family member in the success of family business in trading business in Jabodetabek area. The population of this research is the successor of family business who does business in trading area. The sample of this research is the successor of family business in trading business in Jabodetabek area. Research methods that are used are questionnaire for 150 respondents. The analytical techniques that are used are classic assumption test, multiple regression analysis, $\mathrm{t}$ test, F test and coefficient determination test using SPSS ver. 20.0. The result of classic assumption stated that this regression model is feasible to be used. The test result shows partially that even together there are still a positive and significance between family member and non-family member involvement for the success of family business. The result of the coefficient determination variable stated that the success of family business can be determined by family and non family member variable percentage that is $67,8 \%$ while the rest are determined by other variables.
\end{abstract}

Keywords : Brand Loyalty, Brand Love, Brand Commitment, Willingness to pay a Premium Price.

\section{Pendahuluan}

Pada jaman sekarang yang sudah sangat berkembang ini maka jam tangan sekarang bukan merupakan suatu hal yang dapat di katakan sangat penting karena banyak cara untuk mengetahui jam tidak melalui jam tangan tetapi melalui smartphone atau lainnya. Jam tangan atau arloji di jaman sekarang lebih banyak di manfaatkan sebagai fashion dan bagi kaum tertentu di gunakan untuk menunjukan kelas dari diri mereka. Pada saat ini sangat banyak inovasi terbaru dari para perusahaan jam tangan. Mereka menawarkan jam tangan dengan berbagai kemewahan dan berbagai kecanggihan.

Alfred Davis dan saudara ipar Hans Wilsdorf nya mendirikan suatu perusahaan yang akhirnya menjadi Rolex, di London, Inggris pada tahun 1905. kegiatan komersial utama Wilsdorf dan Davis pada saat itu yaitu terlibat dalam mengimpor suku cadang jam Swiss Hermann Aegler dari swiss ke Inggris dan merakit suku cadang tersebut ke dalam case berkualitas tinggi yang dibuat oleh Dennison dan lain-lain. Ini merupakan jam tangan awal dijual ke toko perhiasan, yang kemudian mereka menempatkan nama mereka sendiri pada jam tersebut. Jam tangan paling awal dari Wilsdorf dan Davis biasanya dibubuhkan "W \& D" dibelakang belakang case tersebut. (Mondani \& Mondani, 2015)

Pada tahun 1908 Wilsdorf mendaftarkan merek "Rolex" dan membuka kantor di La Chaux-de-Fonds, Swiss. Perusahaan dengan Nama "Rolex" telah didaftarkan pada tanggal 15 
November 1915. Buku The Best of Time: Rolex jam tangan: Sebuah Sejarah sah oleh Jeffrey P. Hess dan James Dowling mengatakan bahwa nama itu hanya dibuat. Satu cerita, tidak pernah dikonfirmasi oleh Wilsdorf, menceritakan bahwa nama itu berasal dari frase horlogerie exquise Perancis, yang berarti "jarum jam indah" atau sebagai kontraksi "keunggulan horological". Wilsdorf dikatakan ingin namanya arloji merek menjadi mudah diucapkan dalam bahasa apapun. Hal ini mudah diucapkan dalam banyak bahasa dan, karena semua huruf besar yang memiliki ukuran yang sama, dapat ditulis secara simetris. Itu juga cukup pendek untuk muat pada wajah arloji. (Dowling \& Hess, 2008)

Selama dekade terakhir ini, merek mempunyai peranan yang sangat penting bagi kelangsungan hidup perusahaan. Apalagi pemasaran dimasa kini dan masa yang akan datang menjadi persaingan antar merek, yaitu persaingan untuk merebut konsumen melalui merek. Merek bukan hanya lagi dianggap sebagai sebuah nama, simbol maupun logo. Lebih dari itu merek merupakan nilai yang ditawarkan sebuah produk bagi konsumen yang memakainya. Kotler dan Keller (2016) menyatakan bahwa merek merupakan sarana untuk pembedaan barang-barang antar produsen, bahkan pada tataran yang lebih tinggi lagi, merek dapat memainkan sejumlah peran penting untuk meningkatkan hidup konsumen dan nilai keuangan dari perusahaan. Jadi, merek dapat menjadi sumber kehidupan perusahaan karena itu merek merupakan salah satu keputusan strategis perusahaan. Dan juga merek dapat menjadikan suatu tingkatan tertentu dimana pembeli yang puas dapat mudah memilih suatu produk.

Merek adalah aset yang sangat penting bagi banyak perusahaan dan merupakan dasar untuk keungggulan keuangan dan kompetitif. Hasil sebuah kesuksesan dari merek adalah mampu mempertahankan nilai-nilai tambah dengan membangun hubungan jangka panjang berdasarkan pengetahuan dan pengalaman konsumen sehingga dapat saling berhubungan dan mengintegrasikan merek dan perusahaan. Merek bisa memberikan manfaat yang besar baik bagi produsen maupun konsumen. Adanya persepsi dan keyakinan atas produk yang bisa membuat konsumen ingin terasosiasikan untuk membelinya, sehingga konsumen tidak segan untuk membayar mahal dalam mendapatkan produk dengan merek tertentu. Konsumen mampu membayar lebih tinggi suatu produk karena melekat padanya merek yang merupakan jaminan dalam konsistensi kualitas dan nilai yang diyakini terkandung di dalam merek tersebut. Tanpa adanya merek, konsumen menjadi kurang percaya dan aman sehingga bisa muncul kemungkinan buruk diluar harapan. Dalam persaingan yang sangat cepat, konsumen mempunyai alternatif pilihan atas keputusan pembelian yang sangat banyak. Konsumen akan mudah beralih dari satu produk ke produk lain jika produk yang diproduksi tersebut tidak mampu lagi memuaskan kebutuhan dan keinginannya. (Kotler \& Keller, 2016)

Komitmen merek melibatkan hubungan antara merek dengan diri seorang konsumen. Komitmen pembelian ulang yang ditujukan pada suatu merek produk dalam kurun waktu tertentu secara teratur. Menurut Kazemi (2013) Kekuatan sebuah komitmen merek adalah sesuatu yang membuat seseorang memikul resiko dan konsekuensi dari keputusannya tanpa mengeluh, dan menjalaninya dengan penuh rasa syukur sebagai bagian dari kehidupan yang terus berproses. Komitmen merek didefinisikan sebagai hubungan emosional / psikologis dengan merek dalam suatu golongan produk. Secara menyeluruh, komitmen merek merupakan hal yang paling sering terjadi dalam produk dengan keterlibatan tinggi yang melambangkan konsep diri, nilai, dan kebutuhan konsumen. Komitmen merek dapat didefinisikan sebagai kesertaan emosional psikologis pada sebuah merek dalam sebuah katagori produk. Menurut para peneliti, keterlibatan ego terjadi ketika sebuah produk sangat berkaitan dengan nilai-nilai penting, kebutuhan dan konsep diri pelanggan.

Citra dari sebuah merek bisa mempengaruhi konsumen dalam memilih suatu produk untuk memenuhi kebutuhan dan keinginannya. Adanya fakta bahwa dalam setiap pembelian 
produk memiliki sebuah resiko membuat konsumen ingin mencari informasi terlebih dahulu untuk memperkecil resiko. Konsumen melakukan evaluasi terhadap produk ataupun atribut produk tersebut. Keseluruhan evaluasi itu sebagai citra produk karena citra merupakan realitas yang diandalkan konsumen dalam membuat pilihan. Menurut Ismail dan Gabriella (2012: 389) menyatakan bahwa citra merek merupakan bagian penting dari merek yang kuat yang memungkinkan merek untuk dibedakan antara produk satu dengan produk yang lain. Kotler dan Keller (2016) juga menyatakan bahwa citra merek merupakan suatu hal dari merek yang dapat dikenali dan dilihat, seperti logo, slogan, desain, huruf maupun warna tertentu atau persepsi pelanggan atas sebuah produk yang mampu diwakili oleh mereknya.

Riset tentang teori cinta interpersonal oleh Sternberg pada tahun 1986 yang menyatakan bahwa terdapat tiga komponen dari teori tentang cinta yaitu kedekatan, nafsu dan komitmen. Tiga komponen tersebut sangat berkontribusi terhadap loyalitas dan barang apa yang akan dikonsumsi. Menurut Caroll and Ahuvia (2006) mendefinisikan kecintaan merek sebagai tingkatan ikatan emosional dan keinginan yang dimiliki seseorang terhadap merek. Menurut Ismail dan Gabriella (2012: 388) juga menyatakan bahwa kecintaan konsumen memiliki karakteristik sebagai berikut : (1) Ketertarikan terhadap merek, (2) Keterikatan merek, (3) Penilaian positif terhadap merek, (4) Emosi yang positif dalam merespon merek, dan (5) Deklarasi kecintaan terhadap merek. Konsumen mencintai produknya karena konsumen ingin memiliki keterikatan dengan produk dan akan terus mengkonsumsi produk tersebut.

Suatu merek yang memiliki citra merek yang baik akan menimbulkan dampak positif bagi perusahaan. Konsumen akan menjadi loyal terhadap merek tersebut dan bersedia membayar lebih untuk merek tersebut dibandingkan untuk merek lain. (Aaker, 2009).

\section{Hipotesis}

H1 : Terdapat pengaruh Brand Loyalty terhadap Willingness to pay a Premium Price

$\mathrm{H} 2$ : Terdapat pengaruh Brand Love terhadap Willingness to pay a Premium Price

H4 : Terdapat pengaruh Brand Commitment terhadap Willingness to pay a Premium Price

\section{METODE}

Dalam penelitian ini menggunakan pemilihan sampel secara (non-probability sampling. Teknik pemilihan sampel dalam penelitian ini adalah purposive sampling. Data yang digunakan oleh peneliti dalam penelitian ini adalah data primer. Metode pengumpulan data yang digunakan dalam penelitian ini adalah menggunakan kuesioner atau angket. Dalam penelitian ini digunakan alat statistik SPSS versi 20.0 yang terkomputerisasi, sehingga dapat mempermudah proses pengujian data. Dalam deskripsi subyek penelitian ini akan diuraikan karateristik 150 responden yang ditinjau dari atas dasar karakteristik demografi seperti gender,usia, pekerjaan, lama menggunakan jam Rolex dan jumlah jam yang dimiliki dan dalam deskripsi objek penelitian berisi anggapan responden atas kelompok pernyataan yang meminta mereka untuk menilai variabel Brand Loyalty, Brand Love, Brand Commitment terhadap Willingness to pay a Premium Price.

\section{A. Kerangka Pemikiran}

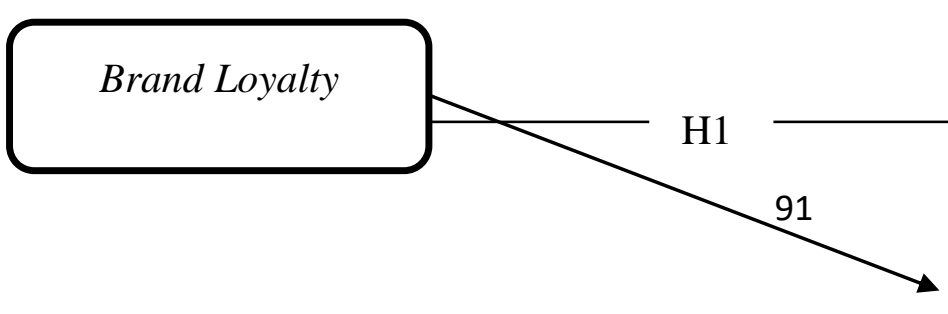




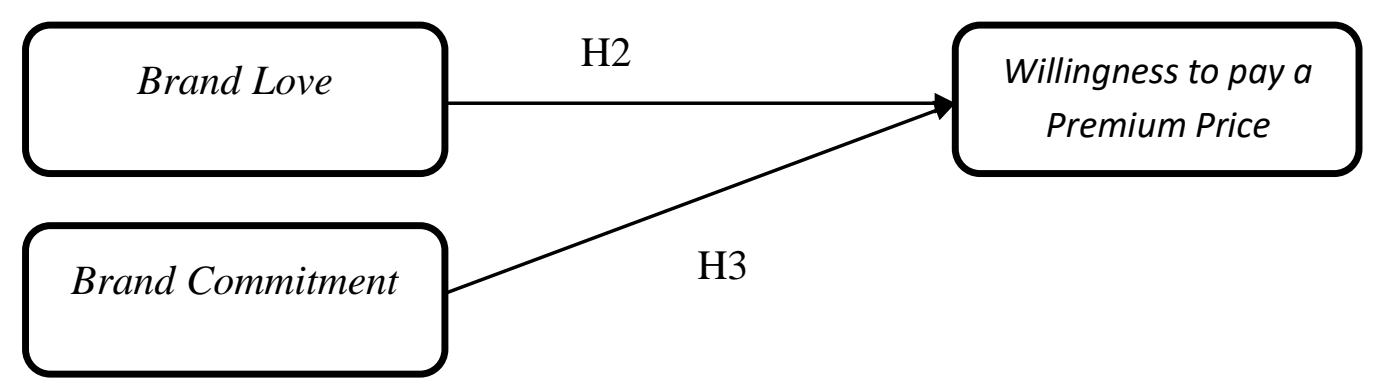

Gambar 1. Research model.

\section{B. Measurement}

Tiga pertanyaan kuesioner mengenai Brand Loyalty (X1) adalah "Saya akan merekomendasikan merek Rolex kepada orang lain", "Saya menganggap diri saya setia dengan merek Rolex", "Merek Rolex sudah menjadi pilihan utama saya". Sedangkan empat pertanyaan kuesioner mengenai Brand Love (X2) adalah "Saya senang membeli dan menggunakan merek Rolex", "Saya memimpikan merek Rolex ini sudah lama sekali", "Saya merasa nyaman menggunakan merek Rolex", "Saya menggunakan merek Rolex sudah lama dan tidak ingin mengganti dengan merek lain". Sedangkan tiga pertanyaan kuesioner mengenai Brand Commitment (X3) adalah "Saya akan kecewa jika tidak menemukan produk merek Rolex di toko", "Saya akan puas bila membeli produk merek Rolex", "Jika merek Rolex mengecewakan saya 1 atau 2 kali saya tidak akan peduli", "Saya ingin mencari tahu informasi mengenai merek Rolex". Sedangkan tiga pertanyaan kuesioner mengenai Willingness to pay a Premium Price (Y1) adalah "Saya lebih memilih berbelanja di toko bermerek Rolex di banding toko lain yang memiliki diskon", "Saya bersedia membayar harga yang lebih tinggi untuk merek Rolex walaupun ada merek lain yang memiliki harga lebih rendah", "Meskipun harga yang lebih murah daripada merek lain, saya lebih memilih untuk membeli merek Rolex". Setiap pertanyaan kuesioner diukur dengan menggunakan 5 poin penilaian dari skala Likert " 1 = sangat tidak setuju" sampai " 5 = sangat setuju".

\section{Sampel Penelitian}

Teknik Sampling yang digunakan untuk mengambil sampel dalam penelitian ini adalah dengan menggunakan teknik purposive sampling. Dikarenakan jumlah populasi tidak diketahui, maka sampel ditentukan oleh peneliti sebanyak 150 responden. Dimana kriteria ini sudah sesuai untuk analisis menggunakan SPSS dengan sampel yaitu 150.

\section{HASIL}

Seluruh kuesioner yang dikembalikan telah diisi dengan lengkap oleh responden, kemudian peneliti memasukkan jawaban yang terdapat pada 150 kuesioner tersebut dan mengolahnya dengan SPSS.

\section{A. Uji Validitas dan Reliabilitas}

Tabel 1. Uji Validitas

\begin{tabular}{|l|l|l|l|}
\hline Variabel & Indikator & $\begin{array}{l}\text { Corrected } \\
\text { Item-Total } \\
\text { Correlation }\end{array}$ & Keterangan \\
\hline
\end{tabular}




\begin{tabular}{|l|l|c|c|}
\hline $\begin{array}{l}\text { Brand } \\
\text { Loyalty }\end{array}$ & Brand Loyalty butir 1 & 0,471 & Valid \\
\hline & Brand Loyalty butir 2 & 0,468 & Valid \\
\hline & Brand Loyalty butir 3 & 0,469 & Valid \\
\hline Brand Love & Brand Love butir 1 & 0,492 & Valid \\
\hline & Brand Love butir 2 & 0,629 & Valid \\
\hline & Brand Love butir 3 & 0,561 & Valid \\
\hline & Brand Love butir 4 & 0,604 & Valid \\
\hline $\begin{array}{c}\text { Brand } \\
\text { Commitment }\end{array}$ & Brand Commitment butir 1 & 0,602 & Valid \\
\hline & Brand Commitment butir 2 & 0,588 & Valid \\
\hline & Brand Commitment butir 3 & 0,546 & Valid \\
\hline & Brand Commitment butir 4 & 0,626 & Valid \\
\hline $\begin{array}{l}\text { Willingness } \\
\text { to pay a } \\
\text { Premium } \\
\text { Price }\end{array}$ & $\begin{array}{l}\text { Willingness to pay a Premium } \\
\text { Price butir 1 }\end{array}$ & 0,729 & Valid \\
\hline & $\begin{array}{l}\text { Willingness to pay a Premium } \\
\text { Price butir 2 }\end{array}$ & 0,750 & Valid \\
\hline & $\begin{array}{l}\text { Willingness to pay a Premium } \\
\text { Price butir 3 }\end{array}$ & 0,727 & Valid \\
\hline
\end{tabular}

Berdasarkan tabel 1 di atas terlihat bahwa nilai CIT lebih dari 0,3 maka dapat di simpulkan bahwa semua pernyataan dari setiap variable adalah valid.

Tabel 2. Uji Reliabilitas

\begin{tabular}{|l|l|l|}
\hline Variabel & Cronbach Alpha & Keterangan \\
\hline Brand Loyalty & 0,656 & Reliabel \\
\hline Brand Love & 0,767 & Reliabel \\
\hline Brand Commitment & 0,784 & Reliabel \\
\hline Willingness to pay a Premium Price & 0,859 & Reliabel \\
\hline
\end{tabular}

Tabel 2. Uji Reliabilitas

Berdasarkan tabel 2 di atas, semua variable penelitian memiliki nilai reliabilitas di atas 0,6 maka dapat disimpulkan bahwa semua variable dapat dikatakan reliabel.

\section{B. Deskripsi Subyek dan Obyek penelitian}

Dalam penelitian ini, diketahui bahwa sebagian besar responden memiliki jenis kelamin pria dengan presentase $53.3 \%$ atau sebanyak 80 orang responden. Sementara sisanya $46.7 \%$ atau sebanyak 70 orang responden berjenis kelamin wanita kemudian diketahui bahwa sebagian besar responden berusia $<25$ tahun sebanyak 35 orang dengan presentase $23,3 \%$, responden berusia 25-40 tahun sebanyak 102 orang dengan presentase $68 \%$ dan responden yang berusia $>40$ tahun sebanyak 13 orang dengan presentase $8,7 \%$. Dan juga diketahui bahwa sebagian besar responden memiliki jam tangan merek Rolex $<5$ tahun sebanyak 96 orang dengan presentase sebesar 64\%, memiliki jam tangan Rolex 5-15 tahun sebanyak 37 orang dengan presentase $24,7 \%$ dan memiliki jam tangan merek Rolex $>15$ tahun sebanyak 17 orang dengan presentase $11,3 \%$. 


\section{Hasil Analisis Data}

Uji multikolonearitas dapat dilihat dari nilai variance inflation factor (VIF). Apabila nilai VIF dibawah 10, maka dalam model regresi tidak terdapat gejala multikolonearitas. Sebaliknya, apabila nilai VIF di atas 10, maka karena nilai VIF kurang dari 10 maka dapat disimpulkan bahwa tidak terdapat multikolonearitas.

Tabel 3. Uji Multikolonearitas

\begin{tabular}{|c|c|c|c|}
\hline No & Variabel & VIF & Keterangan \\
\hline 1 & Brand Loyalty & 1,214 & Tidak terdapat multikolonearitas \\
\hline 2 & Brand Love & 1,315 & Tidak terdapat multikolonearitas \\
\hline 3 & Brand Commitment & 1,305 & Tidak terdapat multikolonearitas \\
\hline
\end{tabular}

\section{Analisis Regresi Ganda}

Berdasarkan pengujian asumsi klasik yang telah dilakukan sebelumnya, maka data yang diperoleh dapat diregresikan untuk mendapat persamaan regresinya. Hasil pengolahan regresi ganda dengan menggunakan perangkat lunak SPSS adalah sebagai berikut :

Tabel 4. Hasil Uji t

\begin{tabular}{|c|c|c|c|c|c|}
\hline \multirow{2}{*}{ Model } & \multicolumn{2}{|c|}{$\begin{array}{c}\text { Unstandardized } \\
\text { Coefficients }\end{array}$} & $\begin{array}{c}\text { Standardized } \\
\text { Coefficients }\end{array}$ & \multirow{2}{*}{$\mathrm{t}$} & Sig \\
\cline { 2 - 4 } & $\mathrm{B}$ & $\begin{array}{c}\text { Std. } \\
\text { Error }\end{array}$ & Beta & & \\
\hline Constant & 0,658 & 0,895 & & 0,735 & 0,463 \\
\hline Brand Loyalty & 0,498 & 0,056 & 0,521 & 8,881 & 0,000 \\
\hline Brand Love & 0,181 & 0,045 & 0,243 & 3,976 & 0,000 \\
\hline Brand Commitment & 0,177 & 0,051 & 0,210 & 3,453 & 0,001 \\
\hline
\end{tabular}

Dari data di atas dapat disimpulkan bahwa uji t memiliki signifikansi di bawah 0,05 maka dapat di katakana bahwa variable memiliki pengaruh secara parsial.

\section{KESIMPULAN}

- Brand Loyalty memiliki pengaruh yang signifikan terhadap Willingness to pay a Premium Price

- Brand Love memiliki pengaruh yang signifikan terhadap Willingness to pay a Premium Price

- Brand Commitment memiliki pengaruh yang signifikan terhadap Willingness to pay a Premium Price

\section{IMPLIKASI MANAJERIAL}

Berdasarkan hasil analisis dan pengelolahan data, maka implikasi hasil penelitian dapat diuraikan sebagai berikut :

- Brand Loyalty

Melihat dari rata-rata pernyataan variable Brand Loyalty dapat disimpulkan bahwa poin 1 yaitu "saya akan merekomendasikan merek Rolex kepada orang lain" memberikan pernyataan paling valid dalam variable Brand Loyalty.

- Brand Love

Melihat dari rata-rata pernyataan variable Brand Love dapat disimpulkan bahwa poin 1 yaitu "saya memimpikan Rolex ini sudah lama sekali" memberikan pernyataan paling valid dalam variable Brand Love. 


\section{- Brand Commitment}

Melihat dari rata-rata pernyataan variable Brand Commitment dapat disimpulkan bahwa poin 1 yaitu "saya ingin mencari tahu informasi mengenai merek Rolex" memberikan pernyataan paling valid dalam variable Brand Commitment.

- Willingness to pay a Premium Price

Melihat dari rata-rata pernyataan variable Willingness to pay a Premium Price dapat disimpulkan bahwa poin 1 yaitu "Saya bersedia membayar harga yang lebih tinggi untuk merek Rolex walaupun ada merek lain yang memiliki harga lebih rendah" memberikan pernyataan paling valid dalam variable Willingness to pay a Premium Price.

- Berdasarkan hasil dari penelitian ini menunjukan bahwa bahwa persentase sumbangan pengaruh variabel independen (Brand Loyalty, Brand Love dan Brand Commitment) terhadap variabel dependen (Willingness to pay a Premium Price) sebesar 58,7\%. Atau variasi variabel independen yang digunakan dalam model (Brand Loyalty, Brand Love dan Brand Commitment) mampu menjelaskan sebesar 58,7\% variasi variabel dependen (Willingness to pay a Premium Price). Sedangkan sisanya sebesar 41,3\% dipengaruhi atau dijelaskan oleh variabel lain yang tidak dimasukkan dalam model penelitian ini.

\section{DAFTAR PUSTAKA}

Aaker, David. (2009). Manajemen Ekuitas Merek. Jakarta : Spektrum.

Albert, Noel \& Dwight Merunka.(2013) "The Role of Brand Love in Consumer-Brand Relationship". Journal of Consumer Marketing. Vol 30. Number 3. 30 (March) 2013.

Ariffin, Zaenal dan S. Amran Tasai. 2015. Bahasa Indonesia Sebagai Mata Kuliah Pengembangan Kepribadian. Cetakan ke-5. Tangerang: Pustaka Mandiri.

Aritonang R, Lerbin. (2007). Riset Pemasaran Teori dan Praktik. Jakarta: Ghalia Indonesia.

Carroll, B \& Ahuvia, A. (2006): Some Antecedents and Outcomes of Brand Love. Marketing Letters, 17, 2, pp. 79-89.

Dowling, J \& Hess, J. (2006). The Best of Time Rolex Wristwatches: An Unauthorized History, $3^{\text {rd }}$ Edition, Pennsylvania: Schiffer Publishing.

Ghozali, Imam 2013. Aplikasi Analisis Multivariate Dengan Program SPSS, Edisi Keenam, Penerbit Universitas Diponegoro

Ghozali, Imam 2012. Konsep dan Aplikasi dengan program AMOS 21.0. Semarang : Badan Penerbit Universitas Diponegoro

Ismail, R. Ahmed dan Gabriella Spinelli. (2012) "Effects of Brand Love, Personality and Image on Word of Mouth". Journal of Fashion Marketing and Management. Vol 16. Number 4. 11 (January) 2012.

Kazemi, Ali , Vahid Moradi , Arash Abbaszadeh \& Javad Pourzamani. "Impact of brand identity on customer loyality and word of mouth communications, considering mediating role of customer satisfaction and Brand Commitment". Journal of Academic Research in Economics and Management Sciences. Vol 2. Number 4. (July) 2013. 
Kotler, P \& Amstrong, G. (2012). Principles of Marketing, $14^{\text {th }}$ Edition, New Jersey: Prentice-Hall Published.

Kotler, P \& Keller, K. L. (2016). Marketing Management, $15^{\text {th }}$ Edition, New Jersey: Pearson Education.

Malhotra, Naresh K. (2010). Riset Pemasaran Pendekatan Terapan. Jakarta: Index.

McFerran, B., Aquino, K., \& Tracy, J. (2014). Evidence for two facets of pride in consumption: Findings from luxury brands. Journal of Consumer Psychology. 2014.

Mondani, G \& Mondani, G. (2015). Rolex Encyclopedia. $1^{\text {st }}$ Edition, Genova: Guido Mondani Editore.

Priyatno, Duwi. 2010. Paham Analisa Statistik Data dengan SPSS. Yogyakarta: Mediakom.

Priyanto, Duwi. 2008. Mandiri Belajar SPSS . Yogyakarta: Mediakom.

Schiffman, L. G., \& Kanuk, L. L. (2010). Consumer Behavior, 10 ${ }^{\text {th }}$ Edition, New Jersey: Pearson Education.

Sekaran, Uma \& Bougie, Roger. (2013). Research Methods for Business. $6^{\text {th }}$ edition. United Kingdom: Wiley 
